\title{
PENERAPAN MODEL PEMBELAJARAN MATEMATIKA REALISTIK PADA POKOK BAHASAN BILANGAN BULAT
}

\author{
Irmina Veronika Uskono*, Kristoforus Djawa Djong, Samuel Igo Leton \\ Pendidikan Matematika Universitas Katolik Widya Mandira \\ *veniuskono@gmail.com
}

Dikirim: 30 Oktober 2019. Diterima: 07 Januari 2020. Dipublikasikan: 31 Januari 2020

\begin{abstract}
ABSTRAK
Tujuan dari penelitian ini adalah mendeskripsikan dan mengetahui keefektifan penerapan model Pembelajaran Matematika Realistik (PMR) dalam meningkatkan kemampuan siswa memahami pokok bahasan Bilangan Bulat pada siswa kelas VII salah satu SMP Negeri di Kota Kupang. Penelitian ini merupakan penelitian tindakan kelas, data dikumpulkan melalui observasi dan tes. Observasi dilakukan pada pra siklus dan pada setiap siklus, sedangkan tes dilakukan pada pra siklus, akhir setiap siklus dan pada akhir dari semua siklus penelitian. Berdasarkan hasil analisis deskriptif terhadap data observasi dan data hasil tes, disimpulkan bahwa; rata-rata data hasil observasi maupun rata-rata data hasil tes menunjukkan adanya peningkatan. Data hasil observasi kemampuan guru mengelola pembelajaran mengalami peningkatan dari siklus I ke siklus II sebesar 0,72. Rata-rata aktivitas siswa juga mengalami peningkatan dari siklus I ke siklus II sebesar 0,91. Rata - rata hasil tes belajar siswa pun menunjukkan peningkatan dari siklus I ke siklus II sebesar 2,89. Dan rata-rata ketuntasan hasil tes siswa secara klasikal juga mengalami peningkatan, yaitu sebesar $25,71 \%$. Pada tes akhir, siswa yang memperoleh skor minimal 60 sebanyak 88,57\%. Karena ketuntasan hasil belajar secara klasikal tercapai, kemampuan guru mengelola pemblajaran efektif, aktivitas siswa dalam pembelajaran efektif dan respon siswa terhadap pembelajaran positif, maka dapat disimpulkan bahwa penerapan model PMR dapat meningkatkan kemampuan siswa memahami materi Bilangan Bulat di SMP kelas VII.
\end{abstract}

Kata kunci: Model Pembelajaran, Pembelajaran Matematika Realistik, bilangan bulat.

\section{ABSTRACT}

The purpose of this study is to describe and to know the effectiveness of the application of the Realistic Mathematics Education (RME) in improving student's ability to understand the subject of integers in class VII students of one of the State Junior High Schools in Kupang City. This research is a classroom action research, data collected through observation and tests. Observations were made at the pre-cycle and each cycle, while the tests were carried out at the pre-cycle, the end of each cycle and the end of all research cycles. Based on the results of the descriptive analysis of observational data and test result data, it was conducted that; the average observation data and the average test result data show an increase. Data from observations of the ability of teachers to manage to learn has increased from cycle I to cycle II by 0.72. The average activity of students also increased from cycle I to cycle II of 0.91 . The average student learning test results also showed an increase from cycle I to cycle II of 2.89. And the average completeness of student's test results in a classic also increased, which is equal to $25.71 \%$. at the final test, students who received a minimum score of 60 were $88.57 \%$. Because the mastery of classical learning outcomes is achieved, the ability of teachers to manage effective learning, student activities ineffective learning, student activities in effective learning and student responses to positive learning, it can be concluded that the application of the RME can improve students' ability to understand integers in class VII students.

Keywords: learning model, realistic mathematic education, integers 


\section{Pendahuluan}

Perkembangan ilmu pengetahuan dan teknologi dewasa ini memungkinkan semua orang untuk dapat memperoleh informasi dengan melimpah, cepat dan mudah dari berbagai sumber dan tempat di dunia. Selain perkembangan yang pesat, perubahan juga terjadi dengan cepat. Karenanya diperlukan kemampuan untuk memperoleh, mengelola dan memanfaatkan informasi untuk bertahan pada keadaan yang selalu berubah, tidak pasti dan kompetitif.

Kemampuan ini membutuhkan pemikiran yang sistematis, logis dan kritis yang dapat dikembangkan melalui pembelajaran matematika. Matematika merupakan salah satu mata pelajaran dari serangkaian mata pelajaran yang mempunyai peranan penting dalam pendidikan yang mendukung perkembangan ilmu pengetahuan dan teknologi. Tidak mengherankan jika pelajaran matematika diberikan kepada semua jenjang pendidikan, mulai dari taman kanak-kanak hingga perguruan tinggi.

Berdasarkan hasil diskusi dengan beberapa guru, dikatakan bahwa dilihat dari hasil belajar siswa dalam pelajaran matematika, nilai mereka selalu di bawah nilai rata-rata bidang studi lain. Hal ini dapat diakibatkan oleh berbagai faktor antara lain: faktor sekolah, faktor siswa, faktor pembelajaran, materi matematika itu sendiri dan faktor lainnya. Bila dilihat dari faktor pembelajaran, menurut Soedjadi (2001a:1) pembelajaran matematika di sekolah kita selama ini terdapat kebiasaan dengan urutan sajian pelajaran sebagai berikut: (1) diajarkan teori/definisi/teorema, (2) diberikan contoh-contoh, (3) diberikan latihan soal. Dalam latihan soal itu umumnya barulah dihadapi bentuk soal "cerita" yang mungkin terkait dengan terapan matematika atau kehidupan sehari-hari. Justru soal bentuk cerita itulah yang selalu saja tidak mudah dipahami siswa atau diselesaikan oleh siswa. Hasil penelitian yang dilakukan oleh Astuti (2018:49) menunjukkan bahwa matematika dianggap sebagai hal yang menakutkan oleh sebagian siswa.

Alternatif usaha yang dilakukan untuk meningkatkan kemampuan matematika (hasil belajar siswa) adalah melalui model Pembelajaran Matematika Realistik (PMR) yang dititikberatkan pada pemberian problem yang dekat dengan kehidupan sehari-hari siswa. Berdasarkan pemikiran Hans Freudenthal, dalam PMR matematika dianggap sebagai aktivitas manusia dan harus dikaitkan dengan realitas (Hadi,2005:19). Menurut filsafat PMR siswa harus diberi kesempatan untuk menemukan kembali (to reinvent) matematika di bawah bimbingan orang dewasa, dan penemuan kembali ide dan konsep matematika tersebut harus dimulai dari penjelajahan berbagai persoalan dan situasi "dunia riil". Selanjutnya siswa diajak untuk mengkonstruksi sendiri pengertian tentang sifat atau definisi atau teorema ataupun model. Dengan demikian, dalam PMR guru harus mengembangkan pengajaran yang interaktif dan memberikan kesempatan kepada siswa untuk secara aktif berpartisipasi dalam proses belajar, sehingga diharapkan dapat memberi kemungkinan siswa lebih mudah memahami matematika yang memang berobjek abstrak.

Sehubungan dengan hal yang telah dikemukakan di atas, penulis mencoba menerapkan model Pembelajaran Matematika Realistik pada pokok bahasan Bilangan Bulat, maka yang menjadi permasalahan dalam penelitian ini yakni: Bagaimana penerapan model Pembelajaran Matematika Realistik untuk meningkatkan kemampuan siswa memahami pokok bahasan Bilangan Bulat?

\section{Metode Penelitian}

Rancangan penelitian yang dipandang sesuai dengan masalah dan tujuan penelitian adalah Penelitian Tindakan Kelas (PTK), dengan prosedur dan proses pelaksnaan penelitian ini menggunakan model penelitian Hopkins (Sanjaya, 2009:53). Penelitian ini dilaksanakan pada siswa kelas VII C salah satu SMP negeri di Kota Kupang. Dalam penelitian ini diperlukan data mengenai kemampuan guru mengelola pembelajaran, data aktivitas siswa, angket respon siswa dan data hasil tes. Sedangkan sumber datanya yaitu guru dan seluruh siswa kelas VII C yang mengikuti pelajaran matematika topik penjumlahan dan pengurangan, perkalian dan pembagian.

Analisis yang digunakan untuk mengetahui ada atau tidak peningkatan hasil belajar tiap siklus dilihat dari rata-rata skor yang dicapai. Siswa dikatakan tuntas belajar jika memperoleh skor minimal $60 \%$ 
dari skor total. Ketuntasan hasil belajar secara klasikal tercapai jika paling sedikit 85\% siswa memperoleh skor minimal 60 pada tes hasil belajar. Analisis data yang digunakan untuk menjawab kriteria keefektifan pembelajaran adalah jika ketuntasan hasil belajar secara klasikal tercapai dan minimal dua dari tiga hal berikut tercapai, yaitu: (1) kemampuan guru dalam mengelola pembelajaran dikategorikan efektif, (2) aktivitas siswa dikatakan efektif, (3) respon siswa terhadap pembelajaran dikatakan positif.

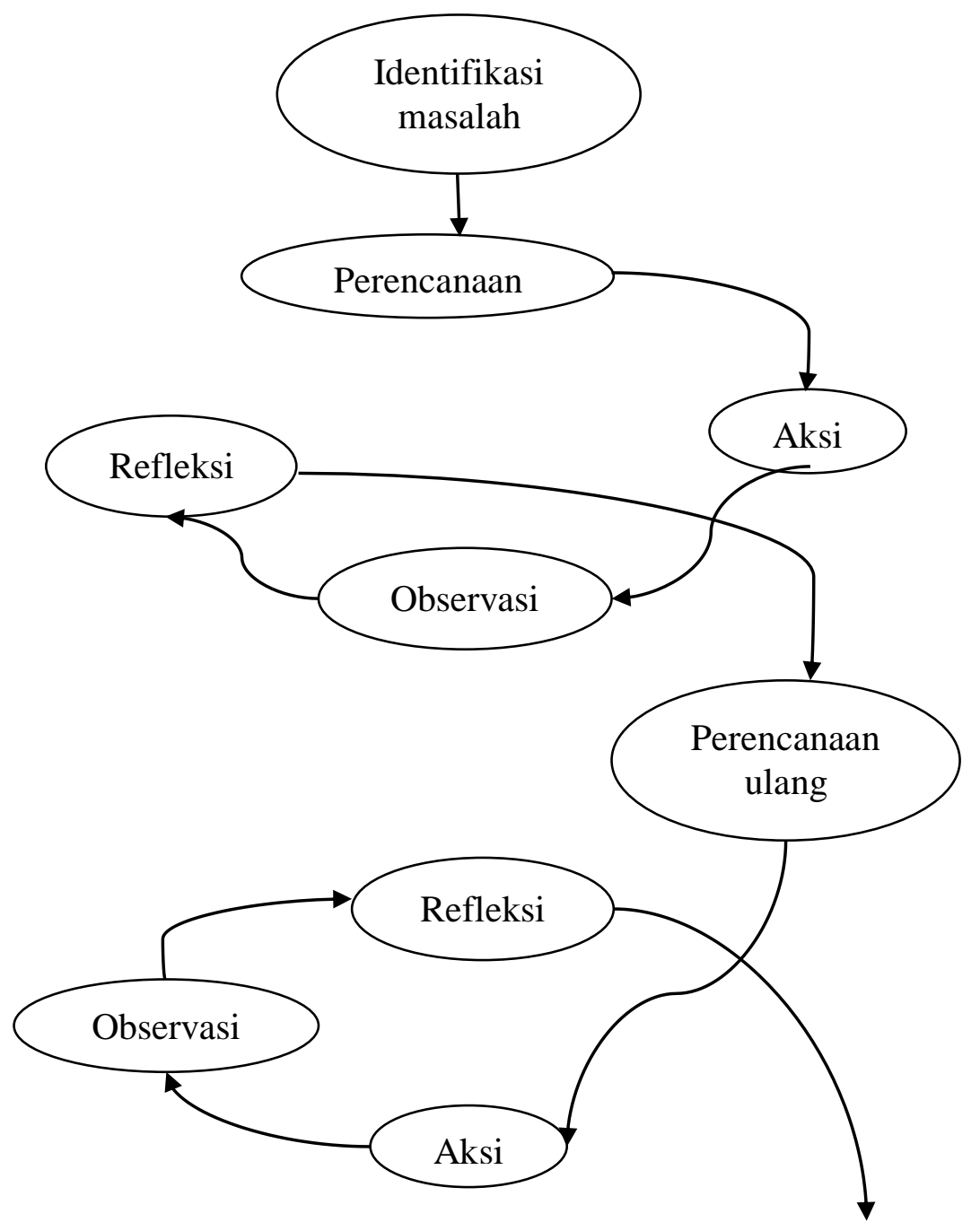

Gambar 1. Penelitian Tindakan Medel Hopkin (Sanjaya, 2009:54)

\section{Hasil Penelitian dan Pembahasan}

\section{Pelaksanaan Pra Siklus}

Kegiatan pra siklus meliputi observasi dan tes awal. Tes awal yang diberikan berupa 10 (sepuluh) soal tes esai yang memuat konsep-konsep dasar bilangan bulat yang pernah dipelajari siswa di sekolah dasar. Skor total maksimum untuk tes awal yang diberikan adalah 20, seorang siswa dikatakan tuntas belajar jika memperoleh skor minimal adalah 12 atau $60 \%$ dari skor total. Ketuntasan belajar klasikal tercapai jika minimal $85 \%$ dari siswa di kelas tersebut tuntas belajar. Berdasarkan data pada tes awal, terlihat bahwa ada 13 siswa tuntas belajar dan 22 siswa yang belum tuntas belajar, sedangkan ketuntasan 
klasikalnya sebesar 37,14\%. Dengan demikian, berdasarkan rata-rata skor yang diperoleh dan dikaitkan dengan kriteria ketuntasan, maka dikatakan bahwa siswa belum tuntas. Materi yang akan diajarkan pada pelaksanaan pembelajaran adalah bilangan bulat yang terdiri dari empat (4) indikator yaitu: (1) Melakukan operasi tambah, kurang bilangan bulat, (2) Menemukan sifat-sifat operasi penjumlahan, pengurangan pada bilangan bulat, (3) Melakukan operasi kali, bagi bilangan bulat, (4) Menemukan sifatsifat operasi perkalian, pembagian pada bilangan bulat. Keempat indikator tersebut disusun dalam dua rencana pelaksanaan pembelajaran yang disesuaikan dengan rencana pelaksanaan pembelajaran menggunakan pendekatan pembelajaran matematika realistik yang telah disiapkan.

\section{Pelaksanaan Siklus I}

Tujuan pembelajaran pada siklus I yaitu siswa dapat melakukan operasi hitung tambah, kurang bilangan bulat dan siswa dapat menemukan sifat-sifat penjumlahan dan pengurangan bilangan bulat. Langkah-langkah pembelajaran dari RPP 1 terdiri dari tiga fase pembelajaran utama yaitu pendahuluan, kegiatan inti dan penutup.

Kegiatan pendahuluan meliputi penjelasan tentang proses pembelajaran yang akan dilaksanakan, pengelompokan siswa dalam 7 kelompok dimana masing-masing kelompok berjumlah 5 orang, memberikan motivasi dan mengkomunikasikan indikator. Kegiatan inti meliputi: (1) meminta siswa memahami masalah kontekstual, (2) guru menjelaskan masalah kontekstual, (3) meminta siswa menyelesaikan masalah kontekstual, (4) membandingkan dan mendiskusikan jawaban, selama diskusi, guru mengarahkan siswa menemukan satu jawaban untuk disepakati yang akan dijadikan kelompok sebagai patokan untuk penyelesaian selanjutnya, kemudian memberi kesempatan kepada wakil dari kelompok untuk menyampaikan hasil diskusi, (5) menyimpulkan, berdasarkan hasil diskusi kelas, guru mengarahkan siswa menarik kesimpulan. Kemudian guru menutup pembelajaran dan memberikan tugas rumah. Selama proses pembelajaran, siswa tampak kurang semangat dalam mengikuti pembelajaran, dan ini tercermin dari ekspresi wajah mereka. Kemungkinan hal ini diakibatkan karena kurangnya motivasi pada kegiatan awal dan juga kehadiran pengamat sebagai mitra peneliti turut mempengaruhi suasana pada awal pembelajaran. Dalam diskusi kelompok, siswa masih terkesan individual yang tercermin dari kesulitan mereka untuk berinteraksi/berdiskusi dengan teman kelompok. Dalam proses pembelajaran ini, peran mitra peneliti yaitu melakukan pengamatan terhadap kemampuan guru (peneliti) mengelola pembelajaran dan aktivitas siswa pada saat proses pembelajaran berlangsung serta membimbing siswa selama proses pembelajaran tersebut. Kemudian hasil pengamatan tersebut diisi pada lembaran observasi yang telah tersedia. Hasil pengamatan tersebut merupakan data observasi untuk siklus I.

Terlihat bahwa ada 3 aspek yang berada pada kategori baik, yaitu menyampaikan materi yang diajarkan, memberikan tugas dan antusias guru. Sedangkan aspek lainnya berada pada kategori cukup. Dengan demikian, berdasarkan rata-rata skor yang diperoleh dan dikaitkan dengan kriteria keefektifan, maka kemampuan guru mengelola pembelajaran tergolong cukup.

Reliabilitas instrumen pengamatan terhadap penerapan pendekatan Pembelajaran Matematika Realistik yaitu $100 \%$, sehingga instrumen yang digunakan adalah baik.

Hasil pengamatan terhadap aktivitas siswa dalam pembelajaran pada siklus I yaitu terlihat bahwa hanya satu aspek yang berada pada kategori kurang baik yaitu menarik kesimpulan suatu konsep. Sedangkan aspek lainnya berada pada kategori cukup. Dengan demikian,berdasarkan rata-rata skor yang diperoleh dan dikaitkan dengan kriteria keefektifan, maka aktivitas siswa pada siklus I tergolong cukup.

Skor total maksimum untuk tes hasil belajar yang diberikan kepada siswa adalah 20. Seorang siswa dikatakan tuntas belajar jika memperoleh skor minimal 12 atau $60 \%$ dari skor total. Ketuntasan belajar secara klasikal tercapai jika minimal $85 \%$ dari siswa di kelas tersebut tuntas belajar. Data hasil belajar siswa pada siklus I dapat dilihat bahwa ada 21 siswa yang tuntas belajar dan ada 14 siswa yang belum tuntas belajar. Ketuntasan secara klasikal mencapai $60 \%$. Dengan demikian, berdasarkan rata-rata skor yang diperoleh dan dikaitkan dengan kriteria ketuntasan, maka dapat dikatakan bahwa penerapan pendekatan pembelajaran matematika realistik pada siklus I, secara klasikal siswa belum tuntas. 
Berdasarkan hasil analisis pada kemampuan guru mengelola pembelajaran, aktivitas siswa, dan hasil tes yang dicapai pada siklus I, maka dapat dikatakan bahwa pelaksanaan siklus I belum berhasil, oleh karena itu dilanjutkan ke siklus II.

Berdasarkan diskusi dan refleksi dengan mitra peneliti diperoleh kesimpulan: 1) Kemampuan guru dalam mengelola pembelajaran dapat dikatakan belum maksimal, misalnya dalam memotivasi siswa dan membimbing siswa dalam kelompok dan juga pengelolaan waktu, 2) Aktivitas siswa dalam kelompok terutama saat berdiskusi masih didominasi oleh beberapa siswa dan siswa masih mengalami kesulitan dalam membuat kesimpulan.

Beberapa saran yang perlu diperhatikan pada pelaksanaan siklus II adalah: 1) Dalam memotivasi dan membimbing siswa selama proses pembelajaran, guru (peneliti) hendaknya lebih kreatif dan guru (peneliti) harus dapat mengelola waktu dengan baik agar pembelajaran berlangsung dengan lebih baik, 2) Mengarahkan siswa agar dapat bekerja sama dalam kelompok, membantu teman dalam kelompok, dan dalam membuat kesimpulan yang baik dan benar.

\section{Pelaksanaan Siklus II}

Kegiatan pembelajaran sama seperti pada siklus I, dengan memperhatikan saran-saran hasil refleksi pada siklus II. Tujuan pembelajaran pada siklus II yaitu siswa dapat melakukan operasi hitung kali dan bagi bilangan bulat dan siswa dapat menemukan sifat-sifat perkalian dan pembagian bilangan bulat.

Langkah-langkah pembelajaran dari RPP 2 secara umum hampir sama dengan langkah-langkah pembelajaran pada pertemuan RPP 1. Dalam pembelajaran ini siswa kelihatan lebih aktif dan antusias terutama dalam diskusi. Ini dapat dilihat dari interaksi siswa dalam kelompok dan dengan guru (peneliti) maupun mitra peneliti. Hasil pengamatan dari mitra peneliti tersebut merupakan data observasi untuk siklus 2. Setelah selesai kegiatan diskusi, selanjutnya siswa diberi tes secara individu yaitu tes siklus II dan tes akhir.

Hasil pengamatan terhadap kemampuan guru mengelola pembelajaran dengan pendekatan pembelajaran matematika realistik dapat bahwa ada tiga aspek yang berada pada kategori sangat baik, yaitu memberikan masalah kontekstul, membimbing kelompok dan antusias guru. Aspek-aspek yang lain berada pada kategori baik. Rata-rata skor secara keseluruhan dari semua aspek yang dinilai berada pada kategori baik sehingga dapat dikatakan bahwa kemampuan guru dalam mengelola pembelajaran tergolong baik dan bila dikaitkan dengan kriteria keefektifan maka kemampuan guru dalam mengelola pembelajaran dikatakan efektif.

Reliabilitas instrumen pengamatan terhadap penerapan pendekatan Pembelajaran Matematika Realistik yaitu 99,08\%, sehingga instrumen yang digunakan adalah baik.

Hasil pengamatan terhadap aktivitas siswa dalam pembelajaran pada siklus II dapat dilihat bahwa ada satu aspek yang berada pada kategori sangat baik, yaitu berdiskusi / bertanya antara siswa dan guru, sedangkan aspek - aspek lainnya berada pada kategori baik. Dengan demikian, berdasarkan rata-rata skor yang diperoleh dapat dikatakan bahwa aktivitas siswa berada pada kategori baik dan bila dikaitkan dengan kriteria keefektifan, maka aktivitas siswa pada siklus II tergolong efektif.

Berdasarkan data hasil tes pada siklus II, terlihat bahwa ada 30 siswa yang tuntas belajar dan 5 siswa yang belum mencapai tuntas belajar. Ketuntasan secara klasikal mencapai 85,71\%. Dengan demikian, berdasarkan rata-rata skor yang diperoleh, maka pada siklus II secara klasikal dikatakan bahwa siswa tuntas belajar. Rata-rata hasil belajar tercapai, dilihat dari adanya peningkatan dari siklus I ke siklus II. Besarnya peningkatan yaitu 2,89. Ketuntasan belajar siswa secara klasikal juga mengalami peningkatan sebesar $25,71 \%$.

Berdasarkan hasil analisis pada kemampuan guru mengelola pembelajaran, aktivitas siswa dan hasil tes yang dicapai pada siklus II, maka dapat dikatakan bahwa pelaksanaan siklus II telah berhasil. Pada akhir dari seluruh rangkaian siklus penelitian diberikan tes. Berdasarkan data hasil tes, dapat diketahui bahwa ada 31 siswa yang tuntas belajar dan ada 4 siswa yang belum mencapai tuntas belajar. 
Ketuntasan klasikal mencapai 88,57\%. Dengan demikian, berdasarkan rata - rata skor yang diperoleh dan dikaitkan dengan kriteria ketuntasan, maka hasil tes akhir secara klasikal dikatakan bahwa siswa tuntas belajar.

Berdasarkan jawaban siswa yang tertuang dalam angket respon siswa, dapat dilihat bahwa jawaban siswa terhadap pernyataan positif untuk setiap aspek yang direspon diperoleh persentasi minimal 77,14\%. Jadi respon siswa terhadap pembelajaran dengan pendekatan realistik adalah positif. Hasil analisis data menunjukkan bahwa kemampuan guru mengelola pembelajaran tergolong efektif, aktivitas siswa tergolong efektif, respon siswa terhadap pembelajaran positif, dan ketuntasan belajar secara klasikal tercapai. Berdasarkan kriteria keefektifan pembelajaran, maka penerapan pendekatan pembelajaran matematika realistik pada pokok bahasan bilangan bulat di kelas VII C SMP dikatakan efektif.

Pembelajaran Matematika Realistik adalah salah satu pendekatan dalam pembelajaran matematika yang menggunakan masalah kontekstual sebagai langkah awal dalam belajar matematika. Siswa memahami kontekstual dan mencoba mengindentifikasi aspek matematika yang ada pada masalah tersebut, siswa diberi kebebasan penuh mendeskripsikan dan menyelesaikan masalah kontekstual dengan caranya sendiri berdasarkan pengalaman atau pengetahuan awal yang dimiliki serta sesuai dengan prinsip dan karakteristik PMR. Kemudian dengan bantuan/tanpa bantuan guru menemukan konsep yang termuat dalam masalah kontekstual tersebut.

Pada awal pelaksanaan pembelajaran, siswa kelihatannya kurang semangat dalam mengikuti pembelajaran. Ini tercermin dari ekspresi wajah mereka. Kemungkinan hal ini diakibatkan karena kurangnya motivasi bagi siswa di kegiatan awal. Pada kegiatan inti, siswa diminta membaca dan memahami masalah di LKS -1, ini sesuai dengan langkah pertama PMR yaitu memahami masalah. Bagi siswa yang belum memahami masalah, guru memberikan kesempatan bertanya dan guru menjelaskan seperlunya, ini sesuai dengan langkah kedua PMR yaitu menjelaskan masalah. Hal ini juga sejalan dengan yang dikemukakan Vygotsky, yaitu tentang Scaffolding yang berarti pemberian sejumlah besar bantuan kepada siswa selama tahap-tahap awal pembelajaran dan kemudian siswa mengambil alih tanggung jawab yang semakin besar segera setelah ia dapat melakukannya (Slavin, 1994:49). Setelah guru menjelaskan, siswa diberi kesempatan untuk menyelesaikan masalah dalam LKS, dan langkah ini termasuk dalam langkah ketiga PMR yakni menyelesaikan masalah. Bagi siswa yang belum menyelesaikan masalah dalam LKS, guru memberikan bantuan seperlunya, berupa pertanyan - pertanyaan yang mengarahkan siswa untuk menemukan jawaban. Setelah siswa menyelesaikan masalah dalam LKS, guru memberi kesempatan kepada siswa untuk membandingkan/mendiskusikan jawaban dengan teman sekelompoknya. Selama diskusi, siswa masih terkesan individual, ini dilihat dari kesulitan mereka untuk berinteraksi/berdiskusi dengan teman kelompok. Guru mengarahkan siswa untuk dapat berinteraksi dalam menemukan satu jawaban untuk disepakati yang akan dijadikan kelompok sebagai patokan untuk penyelesaian selanjutnya. Kemudian siswa diminta tampil ke depan untuk menyampaikan hasil diskusi. Hal ini sejalan dengan langkah PMR yang keempat yaitu membandingkan/mendiskusikan. Dan langkah yang terakhir yaitu melalui diskusi kelas, guru mengarahkan siswa menarik kesimpulan tentang sifat sifat pejumlahan dan pengurangan bilangan bulat.

Pada kegiatan di RPP 2, siswa sudah paham dan mulai antusias dalam diskusi sehingga diskusi berjalan dengan baik. Dalam pengamatan yang dilakukan, guru (peneliti) melihat bahwa adanya respon yang positif yang diberikan siswa terhadap pembelajaran matematika realistik. Antusias siswa tampak jelas saat mereka mulai mengerjakan lembar kerja siswa yang diberikan. Dan langkah yang terakhir yaitu melalui diskusi kelas, guru mengarahkan siswa menarik kesimpulan tentang sifat - sifat perkalian dan pembagian bilangan bulat.

Hasil - hasil analisis terhadap data hasil observasi maupun data hasil tes menunjukkan adanya peningkatan dari siklus I ke siklus II. Rata-rata data hasil observasi kemampuan guru mengelola pembelajaran mengalami peningkatan dari siklus I ke siklus II sebesar 0,72. Rata-rata data aktivitas siswa mengalami peningkatan dari siklus I ke siklus II sebesar 0,91. Rata - rata hasil tes belajar siswa juga 
menunjukkan peningkatan dari siklus I ke siklus II sebesar 2,89. Dan rata-rata ketuntasan hasil belajar klasikal juga mengalami peningkatan, yaitu sebesar $25,71 \%$.

\section{Simpulan dan Saran}

Simpulan

Model Pembelajaran Matematika Realistik dapat meningkatkan kemampuan siswa memahami materi Bilangan Bulat dan efektif digunakan untuk mengajarkan materi Bilangan Bulat.

Saran

Dengan adanya penelitian ini, dapat memberi pengetahuan tambahan kepada guru mata pelajaran matematika untuk menggunakan model Pembelajaran Matematika Realistik khususnya pada pokok bahasan bilangan bulat.

\section{Daftar Pustaka}

Astuti. (2018). Penerapan Realistic Mathematic Education (RME) Meningkatkan Hasil Belajar Matematika Siswa Kelas VI SD. Journal Cendekia: Jurnal Pendidikan Matematika, Volume 1, No 1, Mei 2018, pp 49 -61, E-ISSN: 2579-9258.

Hadi, S. (2005). Pendidikan Matematika Realistik dan Implementasinya. Banjarmasin: Tulip.

Sanjaya, H. W. (2009). Panelitian Tindakan Kelas. Jakarta: Kencana Prenada Media Group.

Slavin, R. E. (1994). Cooperative Learning, Teori, Riset dan Praktik. Bandung: Nusa Media.

Soedjadi, R. (2001a). Pemanfaatan Realitas dan Lingkungan dalam Pembelajaran Matematika. Makalah disampaikan pada Seminar Nasional "Realistic Mathematics Education (RME)"di Jurusan Matematika FMIPA UNESA tanggal 24 Februari 2001 (pp. 1-6). 